\title{
SARS CoV-2 Pathogenesis and Immune Response
}

\section{SARS-CoV-2 Patogenezi ve İmmün Yanıt}

\author{
(i) Harika Öykü DİNÇ, io Pelin YÜKSEL MAYDA
}

Bezmialem Vakıf University Faculty of Pharmacy, Department of Pharmaceutical Microbiology, İstanbul, Turkey

\begin{abstract}
The agent responsible for the epidemic that first appeared in Wuhan, China, in December 2019 was detected to be the new coronavirus (2019-nCoV). Later, the virus that caused respiratory tract infection was discovered to be a member of the beta-coronavirus family, it was named as severe acute respiratory syndrome-CoV2 (SARS-CoV 2 ), and the disease it caused was called $\mathrm{CoV}$ infection disease-19 (COVID-19). The epidemic started in China, spread rapidly first to East Asian countries, then Europe and America, affected the whole world, and was declared a pandemic by the World Health Organization. This review presents an overview of SARS-CoV2 and aims to examine its intracellular pathogenesis and host immune responses.
\end{abstract}

Keywords: Coronavirus, COVID-19, pathogenesis, immunology, SARS-CoV-2

\section{ÖZ}

İlk kez Çin'in Wuhan kentinde Aralık 2019'da ortaya çıkan salgından sorumlu olan etkenin yeni koronavirüs (2019-nCoV) olduğu saptanmıştır. Daha sonra, solunum yolu enfeksiyonuna yol açan bu virüsün beta-CoV ailesine ait olduğu belirlenip, şiddetli akut solunum yolu enfeksiyonu-koronavirüs-2 (SARS-CoV-2) olarak adlandırılmış ve oluşturduğu hastalığa da koronavirüs enfeksiyon hastalığı-19 (COVİD-19) denilmiştir. Çin'de başlayan salgın hızla Doğu Asya ülkelerine sonrasında Avrupa ve Amerika'ya yayılarak, tüm dünyayı etkisi altına almış ve Dünya Sağlık Örgütü tarafından pandemi olarak ilan edilmiştir. Bu derleme, bu virüsle ilgili genel bir bakış açısı sunmakla birlikte, hücre içindeki patogenezini ve konak immün yanıtlarını incelemeyi amaçlamıştır.

Anahtar Sözcükler: Koronavirüs, COVİD-19, patogenez, immünoloji, SARS-CoV-2

\section{Introduction}

Coronaviruses (CoVs) are enveloped, positive-strand RNA viruses with large genomes (26-32 kb) (1). Some of the enveloped $\mathrm{CoVs}$ belonging to the large Coronaviridae subfamily that infect birds and mammals were known to cause self-limited infections in humans, mostly affecting the respiratory system. However, $\mathrm{CoVs}$ became important pathogens again as they caused serious outbreaks in the last 20 years, such as the severe acute respiratory syndrome $\mathrm{CoV}$ (SARS-CoV) in 2002 and the Middle East respiratory syndrome CoV (MERS-CoV) in 2012. In December 2019, the source of the epidemic, which was believed to be associated with seafood and wet animal market in Wuhan, China, was understood to be a new type of coronavirus, and on February 11, the World Health Organization (WHO) named the disease caused by the virus as COVID-19 (2). Molecular studies revealed that the new coronavirus belonged to the beta coronavirus group, and its sequence was $88 \%$ similar to two bat-origin SARS-like CoVs. (3). While initially it was named as 2019-nCoV, the International Commission on Virus Classification announced the name of this novel coronavirus as SARS-CoV-2. Due to a rapid spread of SARS-CoV-2 to many countries of the world and the increased mortality, WHO declared the COVID-19 outbreak 
as a "pandemic" on March 11, 2020 (4). While most of the patients infected with SARS-CoV-2 had a mild clinical course, approximately $5 \%$ of the patients had severe lung damage or even multiple organ failure. Although it varies by country, the average death rate has been reported as $4 \%$. (5). As of the end of June, 216 countries all over the world were affected by the epidemic, 10,021,401 people were confirmed to be infected with SARS-CoV-2, and 499,913 people died (6).

\section{SARS-CoV-2 Replication and Pathogenesis}

There are four main structural proteins in the structure of SARSCoV-2: spike (S), envelope (E), membrane (M), and nucleocapsid (N) glycoproteins, as well as various accessory proteins (7) (Figure 1). Although the spike protein is located on the outer surface of the virus, it consists of two subunits. The $S 1$ subunit plays a role in the binding of the virus to the receptor on the host cell surface, while the $S 2$ subunit mediates cell fusion $(8,9)$. S protein binds to the angiotensin-converting enzyme-2 (ACE-2) receptor of the host cell, and this complex is subjected to a proteolytic process by the host type II transmembrane serine protease (TMPRSS2) enzyme, and the virus enters the cell $(10,11)$. The virus needs both ACE-2 and TMPRSS2 to enter the cell (12). A singlestranded positive-polar RNA with 5 "cap and 3" polyA tail enters the cell. There are about 14 orf's (open reading frames) encoding structural and non-structural proteins in this virus genome (13). First, this genomic RNA is broken down into small pieces by viral proteinases, and non-structural viral replicase polyproteins (pp1a and $\mathrm{pp} 1 \mathrm{~b}$ ) are produced due to the translation of orf 1 and orf2 genes. Polymerase enzyme synthesizes subgenomic mRNAs and acts as a template for synthesized negative polarity sgRNA mRNA. Translation of viral proteins also takes place from mRNAs. Finally, viral proteins and RNA genome combine within virions in the endoplasmic reticulum and Golgi body and are released into the environment as a result of the fusion of vesicles containing viral particles outside the cell with the cell plasma membrane (7) (Figure 2). At this stage, M protein plays an important role in stabilizing the $\mathrm{N}$ protein-RNA complex in the virion, keeping it together, and leaving the cell (13).

It is known that SARS-CoV-2 is transmitted by droplets, just like other human $\mathrm{CoVs}$, and causes primary infection by binding to ACE-2 receptors that are abundant in lower respiratory tract epithelium. The mean incubation period was reported to be 4-5 days before the onset of symptoms, and $97.5 \%$ of symptomatic patients have symptoms within an average of 11.5 days (14). Typical manifestations of COVID-19 include fever and dry cough, although symptoms also include shortness of breath, muscle and/or joint pain, headache, diarrhea, nausea $(5,15,16)$. Acute respiratory distress syndrome (ARDS) can be seen 8-9 days after the onset of symptoms in patients with severe COVID-19 $(15,17)$. Biopsy and autopsy examinations of some COVID-19 patients have shown damage to the alveoli (18). Although the pathophysiology and virulence characteristics of the virus have not been clearly revealed yet, they are possibly related to the structural and non-structural proteins of the virus. Although many studies found ACE-2 receptors, which the virus binds in the small intestine, liver, kidney, and the central nervous system, no study has found viral particles in these organs. SARS-CoV-2 Immunopathology

Host immune system develops various antiviral defense mechanisms against virus infections. Pattern recognition receptors (PRR) in host cells, especially Toll-like receptors (TLR) located in the cell, recognize RNA products formed during viral replication. As a result of this recognition, the immune system is activated by the secretion of type I interferon (type I IFN) from virus-infected cells (19). IFN suppresses protein synthesis in the infected cell by stimulating the RNA-dependent protein kinase enzyme, preventing viral replication and protecting uninfected cells against infection (20). Antigenic structures of pathogens are presented to CD8 $\mathrm{T}$ lymphocytes by antigen-presenting cells via MHC-I, and cytotoxic T-lymphocytes are activated with stimulation of cytokines interleukin [(IL)-12, IFN- $\alpha / \beta)]$. In addition, some dendritic cells can present the processed antigen to both CD4 and CD8 T-lymphocytes by phagocytosing the virus-infected cell (21).

The specific role of humoral and cellular immunity or innate immunity in relation to SARS-CoV-2 is not known, but it probably induces a similar immune response to SARS-CoV and MERS-CoV. RNA viruses are generally recognized by TLR-3

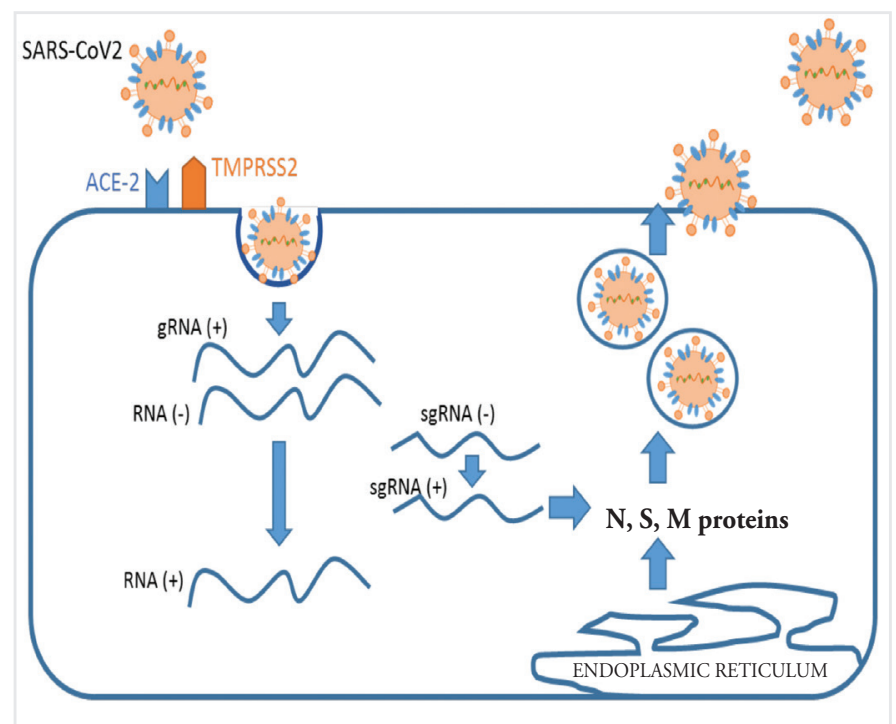

Figure 2. SARS-CoV-2 intracellular cycle

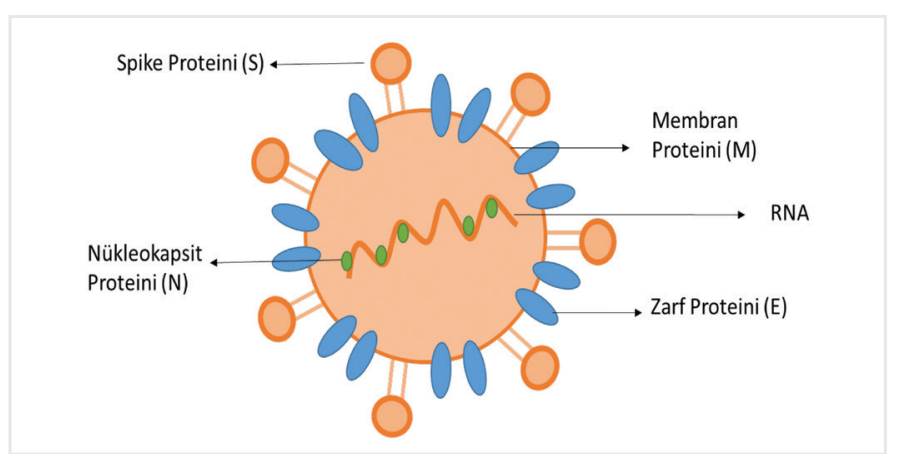

Figure 1. SARS-CoV-2 virus structure 
and TLR-7 endosomal PRRs, and immune system activation begins (22). The production of proinflammatory cytokines and chemokines (IL-6, IP-10, macrophage inflammatory protein $1 \alpha(\mathrm{MIP} 1 \alpha), \mathrm{MIP} 1 \beta$, and MCP1) is triggered by stimulation from neighboring epithelial cells, endothelial cells, and alveolar macrophages (23). These cytokines and chemokines attract monocytes, macrophages, and $\mathrm{T}$ cells to the infection site, and the immune response is enhanced by IFN $-\gamma$ production by the T cells.

Increased release of proinflammatory cytokines causes a cytokine storm in COVID-19 patients. Also, increased expression of proinflammatory cytokines during such cytokine storms causes depletion of lymphocytes (24). Overproduction of proinflammatory cytokines induced by the virus results in cytokine storm, defined as macrophage activation syndrome (MAS) or secondary hemophagocytic lymphohistiocytosis (2527). Severe cases infected with SARS-CoV-2 can be characterized by a cytokine storm that progresses to ARDS; also, high levels of these cytokines in the circulation can lead to shock and tissue damage in the heart, liver, and kidney, as well as respiratory failure or multiple organ failure (28). This high proinflammatory cytokine (especially TNF-a, IL-6, IL-1) level seen in patients with severe COVID-19 is similar to SARS-CoV and MERS$\mathrm{CoV}(29,30)$.

Depending on flowcytometric analysis of peripheral blood in patients infected with SARS-CoV-2 overactivation of $\mathrm{T}$ cells with high cytotoxicity of Th17 and CD8 T cells were and immune damage in these patients was emphasized (18). Previous research demonstrated increased levels of IL-1 $\beta$, IL-6, IL-2, IL8, IL-17, G-CSF, GM-CSF, IP10, MCP1, MIP1 $\alpha$, and TNF- $\alpha$ levels in sera of COVID-19 patients suggesting a clinical picture of cytokine storm $(15,18,31,32)$. In addition, COVID-19associated pneumonia was associated with strong interferon suppression with lymphopenia as part of lung injury, ARDS, and virus-induced immunosuppression (33). Along with low lymphocyte counts, these patients also have a decrease in CD4 and CD8 T cell counts (31). It is thought that SARS-CoV2 may escape the antiviral mechanism (34).

\section{Conclusion}

Although SARS-CoV-2 is in the coronavirus family, its pathophysiology has not been clearly understood yet. Studies on SARS-CoV2, which has become a pandemic in a short time in the world, often refer to the diagnosis and treatment options of the agent, but also include case reports. The number of patients in studies to explain the immune response, especially in COVID-19 patients, is very low. In order to fully and adequately explain the mechanism of immunopathogenesis, larger samples should be used. However, conducting research on virulence properties, intracellular mechanisms, immune stimuli, and escape mechanisms from the host immune response of SARS$\mathrm{CoV} 2$ will bring a different perspective to approaches to the treatment of COVID-19 caused by the pathogen. Unfortunately, zoonotic viruses (Ebola, Zika, Dengue virus, West Nile Fever, MERS-CoV, SARS-CoV), including SARS-CoV-2, are serious threats today in a globalized world. Global warming may induce mutations in viruses by changing the habitat of viruses and their vectors. As a result of increased human mobility, the rapid spread of viruses through infected individuals has been seen again in the COVID-19 pandemic. In addition, it is noteworthy that bats, which are the only flying mammal and contain approximately 4,000 virus species, of which approximately 1,500 of these viruses are coronavirus, should be examined as a possible risk factor. Genomic research about mutations of viruses carrying potential risks is important to protect public health.

Peer-review: Externally peer reviewed.

\section{Authorship Contributions}

Concept: , Design: , Data Collection or Processing: , Analysis or Interpretation: , Literature Search: , Writing:

Conflict of Interest: No conflict of interest was declared by the authors.

Financial Disclosure: The authors declared that this study received no financial support.

\section{References}

1. Su S, Wong G, Shi W, Liu J, Lai ACK, Zhou J, et al. Epidemiology, Genetic recombination, and pathogenesis of coronaviruses. Trends Microbiol 2016;24:490-502.

2. Zhou P, Yang XL, Wang XG, Hu B, Zhang L, Zhang W, et al. A pneumonia outbreak associated with a new coronavirus of probable bat origin. Nature 2020;579:270-3.

3. Lu R, ZhaoX, Li J, Niu P, Yang B, Wu H, etal. Genomic characterisation and epidemiology of 2019 novel coronavirus: implications for virus origins and receptor binding. Lancet 2020;395:565-74.

4. World Health Organization. (2020). https://www.who.int/dg/ speeches/detail/who-director-general-s-opening-remarks-at-themission-briefing-on-covid-19---12-march-2020.

5. Guan WJ, Ni ZY, Hu Y, Liang WH, Ou CQ, He JX, et al. Clinical characteristics of coronavirus disease 2019 in China. N Engl J Med. 2020 Feb 28. doi: 10.1056/NEJMoa2002032. [Epub ahead of print]

6. World Health Organization, Coronavirus disease (COVID-19) pandemic. (2020). Last Accessed Date: 30.06.2020 Available from: https:/www.who.int/emergencies/diseases/novel-coronavirus-2019.

7. Shereen MA, Khan S, Kazmi A, Bashir N, Siddique R. COVID-19 infection: origin, transmission, and characteristics of human coronaviruses. J Adv Res 2020;24:91-8.

8. Fehr AR, Perlman S. Coronaviruses: an overview of their replication and pathogenesis. New York: Springer; 2015:1-23.

9. Walls AC, Park YJ, Tortorici MA, Wall A, McGuire AT, Veesler D. Structure, function, and antigenicity of the SARS-CoV-2 spike glycoprotein. Cell 2020;181:281-92.

10. Glowacka I, Bertram S, Muller MA, Allen P, Soilleux E, Pfefferle S, et al. Evidence that TMPRSS2 activates the severe acute respiratory syndrome coronavirus spike protein for membrane fusion and reduces viral control by the humoral immune response. J Virol 2011;85:4122-34. 
11. Heurich A, Hofmann-Winkler H, Gierer S, Liepold T, Jahn O, Pohlmann S. TMPRSS2 and ADAM17 Cleave ACE2 Differentially and Only Proteolysis by TMPRSS2 Augments Entry Driven by the Severe Acute Respiratory Syndrome Coronavirus Spike Protein. J Virol 2014;88:1293-307.

12. Shulla A, Heald-Sargent T, Subramanya G, Zhao J, Perlman S, Gallagher TA. Transmembrane Serine Protease Is Linked to the Severe Acute Respiratory Syndrome Coronavirus Receptor and Activates Virus Entry J Virol 2011;85:873-82.

13. Astuti I, Ysrafil. Severe Acute Respiratory Syndrome Coronavirus 2 (SARS-CoV-2): An overview of viral structure and host response. Diabetes Metab Syndr 2020;14:407-12.

14. Lauer SA, Grantz KH, Bi Q, Jones FK, Zheng Q, Meredith H, et al. The incubation period of coronavirus disease 2019 (COVID-19) from publicly reported confirmed cases: estimation and application. Ann Intern Med 2020;172:577-82.

15. Huang C, Wang Y, Li X, Ren L, Zhao J, Hu Y, et al. Clinical features of patients infected with 2019 novel coronavirus in Wuhan, China. Lancet 2020;395:497-506.

16. Chen G, Wu D, Guo W, Cao Y, Huang D, Wang H, et al. Clinical and immunologic features of severe and moderate coronavirus disease 2019. J Clin Invest 2020;130:2620-9.

17. Wang D, Hu B, Hu C, Zhu F, Liu X, Zhang J, et al. Clinical characteristics of 138 hospitalized patients with 2019 novel coronavirus-infected pneumonia in Wuhan, China. JAMA 2020;323:1061-9.

18. Xu Z, Shi L, Wang Y. Pathological findings of COVID-19 associated with acute respiratory distress syndrome. Lancet 2020;8:420-2.

19. Abbas AK, Lichtman AH, Pillai S. Basic Immunology: Functions and Disorders of the Immune System. 4th ed. Philadelphia: Elsevier Saunders; 2014.

20. Doan T, Melvold, Viselli S, Waltwnbaugh C. Lippincott's illustrated reviews serisinden: İmmünoloji. Ed: Deniz G, Erten G, Camcıŏlu Y. Nobel Tip Kitabevleri, 2. Basım, 2017.

21. Abbas AK, Lichtman AH, Pillai S. Cellular and Molecular Immunology. 8th ed. Philadelphia: Elsevier Saunders; 2015.

22. Felsenstein S, Herbert JA, McNamara PS, Hedrich CM. COVID-19: Immunology and treatment options. Clin Immunol 2020;215:108448.
23. Tay ZM, Poh CM, Rénia L, MacAry PA, Ng LFP. The trinity of COVID-19: immunity, inflammation and intervention. Nature Rev Immunol 2020;20:363-74.

24. Cron RQ, Chatham WW. The rheumatologist's role in Covid-19. J Rheumatol 2020;47:639-42.

25. George MR. Hemophagocytic lymphohistiocytosis: review of etiologies and management. J Blood Med 2014;5:69-86.

26. Ramos-Casals M, Brito-Zeron P, Lopez-Guillermo A, Khamashta MA, Bosch X. Adult haemophagocytic syndrome. Lancet (London, England) 2014;383:1503-16.

27. McGonagle D, Sharif K, O’Regan A, Bridgewood C. Interleukin-6 use in COVID-19 pneumonia related macrophage activation syndrome. Autoimmun Rev 2020;19:102537.

28. Cao X. COVID-19: immunopathology and its implications for therapy. Nat Rev Immunol 2020;20:269-70.

29. Wong CK, Lam CW, Wu AKL, Ip WK, Lee NLS, Chan HIS, et al. Plasma inflammatory cytokines and chemokines in severe acute respiratory syndrome. Clin Exp Immunol 2004;136:95-103.

30. Min CK, Cheon S, Ha NY, Sohn KM, Kim Y, Aigerim A, et al. Comparative and kinetic analysis of viral shedding and immunological responses in MERS patients representing a broad spectrum of disease severity. Sci Rep 2016;6:25359

31. Qin C, Zhou L, Hu Z, Zhang S, Yang S, Tao Y, et al. Dysregulation of immune response in patients with COVID-19 in Wuhan, China. Clin Infect Dis 2020;71:762-8.

32. Tan M, Liu Y, Zhou L, DengX, Li F, Liang K, etal. Immunopathological characteristics of coronavirus disease 2019 cases in Guangzhou, China. Immunology 2020;160:261-8.

33. McGonagle D, Sharif K, O'Regan A, Bridgewood C. The role of cytokines including interleukin-6 in COVID-19 induced pneumonia and macrophage activation syndrome-like disease. Autoimmun Rev 2020;19:102537.

34. Yi Y, Lagniton PNP, Ye S, Li E, Xu RH. COVID-19: what has been learned and to be learned about the novel coronavirus disease. Int $\mathrm{J}$ Biol Sci 2020;16:1753-66. 